Archives of Agriculture and Environmental Science

\title{
Impact of industrial wastewater disposal on surface water bodies in Kalingarayan canal, Erode district, Tamil Nadu, India
}

\author{
T. Mohanakavitha ${ }^{1}$, K. Shankar ${ }^{*}$ (D) , R. Divahar ${ }^{3}$, T. Meenambal ${ }^{4}$ and R.Saravanan ${ }^{5}$ \\ ${ }^{1}$ Assistant executive Engineer, Erode, Tamil Nadu, INDIA \\ ${ }^{2}$ Department of Applied Geology, School of Applied Natural Science, Adama Science and Technology University, ETHIOPIA \\ ${ }^{3}$ Department of Civil Engineering, Aarupadai Veedu Institute of Technology, Paiyanoor, Chennai, Tamil Nadu, INDIA \\ ${ }^{4}$ School of Civil Engineering and Architecture, Adama Science and Technology University, ETHIOPIA \\ ${ }^{5}$ Department of Civil Engineering, MIET Engineering College, Trichy, Tamil Nadu, INDIA \\ *Corresponding author's E-mail: geoshankar1984@gmail.com
}

\section{ARTICLE HISTORY}

Received: 12 November 2019

Revised received: 03 December 2019

Accepted: 04 December 2019

\section{Keywords}

Kalingarayan canal

Industrial effluents

Sewage water

Tanneries and dyeing industries

\begin{abstract}
The Kalingarayan canal is crossing the major textile town Erode which is abundantly occupied by textile units. Major streams carrying the untreated / semi treated industrial effluents are mixed into the canal. However, the gradual introduction of a large number of new chemical compounds and the technologies has resulted in a much higher number of contaminants today. The original situation, which local intense pollution from a limited number of well-defined sources has been transferred into a situation with widespread contamination by a large variety of compounds from a multitude of sources. Continuous disposal of industrial effluents on the canal, limited assimilate capacity of the canal and also leads to groundwater pollution. Kalingarayan canal has helped to cultivate more than 6000 hectares. For the past few years, Kalingarayan farmers and cattle are experiencing various problems. The area of cultivation is reduced to 3000 hectares because of the contamination in the canal by the different polluting industries like tanneries, textiles and dyeing units located in Erode and Tirupur areas. Hence yield on their lands has decreased to a certain extent. Thus, this study gives a clear picture of pollution sources, types of effluents added in the canal. The scope of the present study is to assess the impact on the surface water of the Kalingarayan canal, a comprehensive experimental study to identify the pollutant levels in the surface water of the Kalingarayan canal and to suggest a suitable remedial measure to handle this problem.
\end{abstract}

(C)2019 Agriculture and Environmental Science Academy

Citation of this article: Mohanakavitha, T., Shankar, K., Divahar, R., Meenambal, T. and Saravanan, R. (2019). Impact of industrial wastewater disposal on surface water bodies in Kalingarayan canal, Erode district, Tamil Nadu, India. Archives of Agriculture and Environmental Science, 4(4): 379-387, https://dx.doi.org/10.26832/24566632.2019.040403

\section{INTRODUCTION}

The Bhavani is a river of southern India, a tributary of the Kaveri. A small barrage across the river Bhavani was built by Kalingarayan in $1283 \mathrm{AD}$ to feed the 56-mile-long Canal build for irrigation purposes, which is now known by his name Kalingarayan Canal. Bhavani river joins the River Noyyal at Aavudaiaaparai is more or less a perennial river fed mostly by the southwest monsoon. The northeast monsoon also supplements its water resources (Mohanakavitha et al., 2019a). Before the development of industries near the canal, the water in the canal was used for irrigation and drinking water. Because of significant industrial and agricultural development, as well as an increase in the city's population the water quality gradually deteriorated in the canal (Sivakumar et al., 2010). There are 39 leather processing units, more than 10 major textiles processing units, less than 150 Dyeing and Bleaching units present in the Kalingarayan canal command area. There are more than 57 Bleaching units in the command area operating without any approval (Sivakumar et al., 2010; Gayathri et al., 2013). The amount of treated and untreated wastes discharged into the canal by domestic and industrial activities which deteriorated 
the water bodies and make them unfit for many useful purposes (Mariraj Mohan and Vanalakshmi, 2013; Samuel Rajkumar and Nagan, 2011; Gayathri et al., 2013; Palanisamy et al., 2007). The Kalingarayan canal near Bhavani town receives wastewaters at different places from industries along with domestic sewage (Mohanakavitha and Meenambal, 2013). To study the impact of the industrial effluents and domestic sewage on the quality of surface water in the Kalingarayan canal, water samples were collected from some areas and the samples were analyzed for various physicochemical parameters.

The quality of groundwater is influenced by natural and anthropogenic activities (Farooq and Ustad, 2015). Chandan et al. (2013) made a study to identify the causes, status, impacts and degree of water pollution of Buriganga River. From the assessment, it is revealed that the river water was highly polluted by both natural and anthropogenic activities (industries and agrochemicals). Thoker et al. (2012) discussed the impact of dye industrial effluent on the physicochemical characteristics of Kshipra River, Ujjain City, India. They made an assessment of water quality being polluted by the effluents. The parameters selected for the study were $\mathrm{pH}$, temperature, electrical conductivity, total solids (TS), total dissolved solids (TDS), total suspended solids (TSS), dissolved oxygen (DO), chemical oxygen demand (COD), total alkalinity, total hardness and chloride content.

Tenagne (2009) studied the impact of urban storm water run-off and domestic waste effluent on water quality of Lake Tana and local groundwater near the city of Bahirdar, Ethiopia. From the result found during the study period, major conclusions were drawn. The run-offs collected from areas where hotels and other commercial centers are located have an elevated value of nitrogen and phosphorus which are excessive in the concentration that causes eutrophication of the lake. Spatial variation of groundwater quality depends on the geological formation through which it flows and on anthropogenic activities in the groundwater basin (Aravindan and Shankar, 2011; Shankar et al., 2010; 2011; 2011a; 2011b; Venkateswaran et al., 2012; Kawo and Shankar, 2018; Mohanakavitha et al., 2019b). Water chemistry analysis can be used as a tool for checking groundwater suitability for drinking and irrigation purposes, numerous studies were conducted in south India (Palanisamy et al., 2007; Geetha et al., 2008; Kulandaivel et al., 2009; Sivakumar et al., 2011; Aravindan et al., 2008; 2010; 2011; Zahir Hussain and Rajadurai, 2013; Abdul Bari and Vennila, 2014; Abdul et al., 2015; Mahalakshmi et al., 2018; Balusamy and Indrani, 2018; Mohanakavitha et al., 2019a). Govindarajalu (2003) studied the nature and impact of water pollution in the Noyal river basin in Coimbatore, Erode and Karur districts. The main thrust on the study is on the health status of villagers, agriculture and the livestock population. For this purpose 31 villages and 600 households were selected for the primary survey. To understand the magnitude of the impact of water pollution on the health status of the villagers, three major health camps were conducted. It is evident from the study that almost all the 31 sampled villages are affected by the industrial effluent.

Moreover, Kiran (2010) determined the physicochemical and bacteriological parameters that deteriorate the quality of drinking water at the source of Vadgam taluk in Gujarat, India and evaluated for its parameters of temperature, colour, odor, turbidity, electrical conductivity (EC), $\mathrm{pH}$, total dissolved solids (TDS), total alkalinity, chemical oxygen demand (COD), chloride, fluoride, calcium and magnesium. Quality of the sample was compared with drinking water standards of ICMR (Indian Council of Medical Research, 1975) and EU (European Union 1998). For the statistical analysis, values of mean, standard deviations and correlation co-efficient ( $r$ ) were also calculated for these water quality characteristics. It is concluded that the quality of water samples is acceptable to the majority of the physicochemical parameters but as TDS values of most of the samples are violating the desirable limit suggested by ICMR, the water should be treated properly before its usage as drinking water to avoid possible adverse effects. From the literature study, it is understood that water pollution cause undesirable changes in the chemical and physical properties of water which are not favorable to domestic purposes. The changes in water quality are due to the physical and chemical characteristics of the effluents received by the canal water. The contamination of water bodies such as lakes, rivers, oceans, aquifers and groundwater causes environmental degradation when pollutants are directly or indirectly discharged into water bodies without adequate treatment to remove harmful compounds (Kumar et al., 2018; Kumar et al., 2019). The Kalingarayan Canal is one of the historically important sources of water for irrigation in the Erode district. The water in the channel was recently polluted by untreated tannery and textile effluents (Balusamy and Indrani, 2018). It was therefore decided that a study on water quality and its polluting load is felt necessary to the users of the canal water. The water quality is analyzed for physicochemical characteristics. It was felt necessary to evaluate the quality of the water used in irrigation and other purposes in the Canal. This study assesses the quality of canal water and the impacts of industry effluents. This study will be very useful in understanding the impact of effluent dumping in the Canal and the impact on water quality in terms of irrigation and environmental impacts.

\section{MATERIALS AND METHODS}

\section{Study area and its location}

The Bhavani River, the second largest river in Tamil Nadu, begins in the Western Ghats upper regions of Nilgiris. In the district of Erode, a small amount of water from the Bhavani River is diverted into a canal called the Kalingarayan Canal near Bhavani Town for irrigation purposes. The Kalingarayan Canal is a 56-mile irrigation canal. The Kalingarayan Canal is located on the western bank of the river Cauvery at $77^{\circ} 40^{\prime} \mathrm{E}$ to $77^{\circ} 48^{\prime} \mathrm{E}$ longitude and $11^{\circ} 16^{\prime} \mathrm{N}$ to $11^{\circ} 26^{\prime} \mathrm{N}$ with an area of $7621 \mathrm{Sq} . \mathrm{km}$ (Figure 1). The 750 year old Kalingarayan canal travels about 90 $\mathrm{km}$ from Kalingarayan anaicut to Avudayaparai. It was built by Kongu chieftain Kalingarayan and finished in the year 1283 . The canal has been designed with a meandering route to maximize the benefit of the land. It is 534 feet above sea level where it originates and 412.40 feet above sea level, where it merges with 

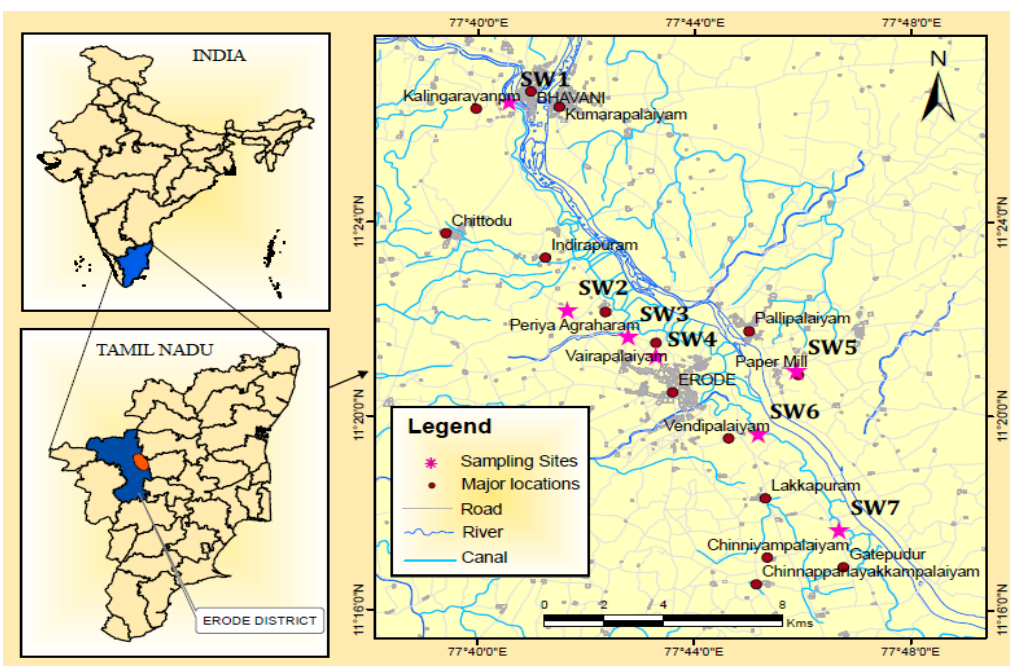

Figure 1. Location map with sampling sites in the study area.

Table 1. Locations of surface water samples in the study area.

\begin{tabular}{llll}
\hline Sample Code & Latitude & Longitude & Sampling Locations (Polluting factors) \\
\hline SW1 & $11^{\circ} 26^{\prime} 26.69^{\prime \prime} \mathrm{N}$ & $77^{\circ} 40^{\prime} 36.27^{\prime \prime} \mathrm{E}$ & Kalingarayan Anicut (Agricultural Activities) \\
SW2 & $11^{\circ} 23^{\prime} 13.92^{\prime \prime} \mathrm{N}$ & $77^{\circ} 41^{\prime} 43.78 " \mathrm{E}$ & Chunnambu Oodai (Tanneries) \\
SW3 & $11^{\circ} 21^{\prime} 49.29 " \mathrm{~N}$ & $77^{\circ} 42^{\prime} 43.45^{\prime \prime} \mathrm{E}$ & Convent School (Domestic area) \\
SW4 & $11^{\circ} 21^{\prime} 44.96 " \mathrm{~N}$ & $77^{\circ} 43^{\prime} 16.18^{\prime \prime} \mathrm{E}$ & Vairapalayam (Dyeing units) \\
SW5 & $11^{\circ} 21^{\prime} 27.98^{\prime \prime} \mathrm{N}$ & $77^{\circ} 44^{\prime} 12.87^{\prime \prime} \mathrm{E}$ & Pallipalayam (Paper mills) \\
SW6 & $11^{\circ} 19^{\prime} 37.77^{\prime \prime} \mathrm{N}$ & $77^{\circ} 45^{\prime} 9.56 " \mathrm{E}$ & Vendipalayam (Domestic area) \\
SW7 & $11^{\circ} 17^{\prime} 37.41^{\prime \prime} \mathrm{N}$ & $77^{\circ} 46^{\prime} 39.02 " \mathrm{E}$ & Colony Pudur (Domestic area) \\
\hline
\end{tabular}

Table 2. Parameters and methods for surface water analysis.

\begin{tabular}{ll}
\hline S.N. & Parameters of water analysis \\
\hline 1 & $\mathrm{pH}$ in standard units \\
2 & Electrical Conductivity in $\mu \mathrm{s} / \mathrm{cm}$ \\
3 & Total dissolved Solids in $\mathrm{mg} / \mathrm{L}$ \\
4 & Total Suspended Solids (TSS) \\
5 & Dissolved Oxygen, COD in $\mathrm{mg} / \mathrm{L}$ \\
6 & Biochemical Oxygen Demand, BOD in $\mathrm{mg} / \mathrm{L}$ \\
7 & Nitrates in $\mathrm{mg} / \mathrm{L}$ \\
8 & Phosphate in $\mathrm{mg} / \mathrm{L}$ \\
\hline
\end{tabular}

the River Noyyal. The channel goes through a serpentine route. The canal connects the rivers Bhavani and Noyyal, the two main Cauvery tributaries. The land survey showed that the area irrigated is 15,743 acres.

Sample collection and sampling procedure

A study was conducted from 2014-2015 and seven surface water samples were collected from different sampling locations on the way to the Canal, at a stretch of about $35 \mathrm{~km}$ from Kalingarayan Anaicut to Colony Pudur. Seven stations were selected as sampling points in the Kalingarayan Canal for the season's viz., Pre-monsoon (June, July, and August), Monsoon (September, October, and November), post-monsoon (December, January, February) and summer (March, April, and May). The study area of the canal was the starting place where the discharge of domestic sewage and washing of vehicles, bathing of animals, human activities releasing of municipal wastes as the main sources of pollutants in the Kalingarayan canal (Balusamy and Indrani, 2018). Hence the study has been carried out to analyze the physicochemical parameters of the canal water. Surface water samples from the Kalingarayan canal were collected from different sampling sites in Table 1. Two liters of wastewater prior

\begin{tabular}{|c|c|}
\hline Methods & Instrumentation \\
\hline \multirow{4}{*}{ Potentiometer } & $\mathrm{pH}$ meter \\
\hline & Conductivity Meter \\
\hline & Gravimetric method \\
\hline & Oven/ Gravimetric method \\
\hline Winkler's method & Titration \\
\hline $\begin{array}{l}\text { Brucine method } \\
\text { Stannous chloride method }\end{array}$ & UV -Vis Spectrophotometer \\
\hline
\end{tabular}

to mixing with the watercourses from each station were collected in thoroughly rinsed plastic containers, labeled and brought to the approved laboratory on a monthly basis. The samples were analyzed using a standard procedure (APHA, 2012) given in Table 2. The $\mathrm{pH}$ of water samples were measured in the field. Samples were subjected to filtration prior to chemical analysis. The samples were preserved in the laboratory at $4^{\circ} \mathrm{C}$ and various physicochemical parameters were determined (Tripathi et al., 1990; 2012). The values obtained for various physicochemical parameters after the analytical study are given in Table 3. All the samples analyzed were not having any objectionable colour, appearance, taste or odour. Summary of the measured physicochemical parameters and the calculation of the maximum, minimum, mean and standard deviations found in different water samples and the final results of the physicochemical concentration are compared by the World Health Organization (WHO, 2011) as shown in Table 3. Statistical analysis was carried out using Statistical Package for Social Sciences (SPSS 10.0). The correlation coefficient values among the parameters for canal ground water are presented in Tables 4a-d. 
Table 3. Physicochemical parameters after the analytical study.

\begin{tabular}{|c|c|c|c|c|c|c|c|c|c|c|c|c|c|}
\hline \multirow{2}{*}{ Parameters } & \multirow{2}{*}{ Seasons } & \multicolumn{7}{|c|}{ Physicochemical Concentration } & \multicolumn{4}{|c|}{ Statistical data } & \multirow{2}{*}{$\begin{array}{l}\text { WHO } \\
(2011)\end{array}$} \\
\hline & & SW1 & SW2 & SW3 & SW4 & SW5 & SW6 & SW7 & Min & Max & Avg & STD & \\
\hline \multirow{4}{*}{$\mathrm{pH}$} & $\begin{array}{l}\text { Pre- } \\
\text { monsoon }\end{array}$ & 7.38 & 7.58 & 7.69 & 7.61 & 7.7 & 7.61 & 7.4 & 7.38 & 7.7 & 7.57 & 0.13 & \multirow{4}{*}{$6.5-8.5$} \\
\hline & Monsoon & 7.12 & 7.2 & 6.9 & 6.92 & 7.5 & 7.31 & 7.4 & 6.9 & 7.5 & 7.19 & 0.23 & \\
\hline & $\begin{array}{l}\text { Post- } \\
\text { monsoon }\end{array}$ & 7.9 & 8.12 & 8.6 & 7.94 & 7.4 & 7.2 & 7.3 & 7.2 & 8.6 & 7.78 & 0.51 & \\
\hline & Summer & 6.88 & 7.42 & 7.56 & 7.4 & 7.26 & 7.8 & 7.78 & 6.88 & 7.8 & 7.44 & 0.32 & \\
\hline \multirow{4}{*}{$\begin{array}{l}\text { Conductivity } \\
(\mu \mathrm{S} / \mathrm{cm})\end{array}$} & $\begin{array}{l}\text { Pre- } \\
\text { monsoon }\end{array}$ & 306 & 314 & 521 & 400 & 420 & 417 & 420 & 306 & 521 & 399.71 & 72.99 & \multirow{4}{*}{1000} \\
\hline & Monsoon & 340 & 370 & 396 & 420 & 460 & 530 & 460 & 340 & 530 & 425.14 & 64.02 & \\
\hline & $\begin{array}{l}\text { Post- } \\
\text { monsoon }\end{array}$ & 1600 & 7850 & 8280 & 4600 & 500 & 510 & 480 & 480 & 8280 & 3402.86 & 3502.03 & \\
\hline & Summer & 410 & 362 & 380 & 386 & 552 & 440 & 510 & 362 & 552 & 434.29 & 71.55 & \\
\hline \multirow{4}{*}{ TDS (mg/L) } & $\begin{array}{l}\text { Pre- } \\
\text { monsoon }\end{array}$ & 230 & 246 & 394 & 310 & 326 & 320 & 324 & 230 & 394 & 307.14 & 54.84 & \multirow{4}{*}{500} \\
\hline & Monsoon & 270 & 290 & 308 & 322 & 350 & 390 & 350 & 270 & 390 & 325.71 & 40.86 & \\
\hline & $\begin{array}{l}\text { Post- } \\
\text { monsoon }\end{array}$ & 1010 & 4042 & 4190 & 2510 & 2400 & 2300 & 3000 & 1010 & 4190 & 2778.86 & 1096.19 & \\
\hline & Summer & 308 & 266 & 270 & 278 & 380 & 310 & 356 & 266 & 380 & 309.71 & 43.93 & \\
\hline \multirow{4}{*}{ TSS (mg/L) } & $\begin{array}{l}\text { Pre- } \\
\text { monsoon }\end{array}$ & 3 & 2.9 & 3.26 & 3.1 & 4.12 & 4.2 & 3.98 & 2.9 & 4.2 & 3.51 & 0.57 & \\
\hline & Monsoon & 9 & 8.4 & 8.1 & 12 & 11 & 12.4 & 13 & 8.1 & 13 & 10.56 & 2.03 & \\
\hline & $\begin{array}{l}\text { Post- } \\
\text { monsoon }\end{array}$ & 32 & 46 & 51 & 49 & 50 & 52.3 & 54.2 & 32 & 54.2 & 47.79 & 7.42 & \\
\hline & Summer & 11 & 8.6 & 9.3 & 14.6 & 12 & 11.2 & 14.6 & 8.6 & 14.6 & 11.61 & 2.34 & \\
\hline \multirow{4}{*}{$\mathrm{COD}(\mathrm{mg} / \mathrm{L})$} & $\begin{array}{l}\text { Pre- } \\
\text { monsoon }\end{array}$ & 41 & 90 & 84 & 72.6 & 70.1 & 84 & 48 & 41 & 90 & 69.96 & 18.81 & \multirow{4}{*}{10} \\
\hline & Monsoon & 23 & 93 & 82 & 72 & 72 & 79 & 29 & 23 & 93 & 64.29 & 27.15 & \\
\hline & $\begin{array}{l}\text { Post- } \\
\text { monsoon }\end{array}$ & 69 & 174 & 179 & 148 & 84 & 83.4 & 82.3 & 69 & 179 & 117.10 & 47.92 & \\
\hline & Summer & 30.6 & 69 & 70 & 71.1 & 86 & 89 & 26 & 26 & 89 & 63.10 & 25.08 & \\
\hline \multirow{4}{*}{ BOD (mg/L) } & $\begin{array}{l}\text { Pre- } \\
\text { monsoon }\end{array}$ & 8.1 & 14 & 13.1 & 10.4 & 10.8 & 11.9 & 7.9 & 7.9 & 14 & 10.89 & 2.33 & \multirow{4}{*}{5} \\
\hline & Monsoon & 3.8 & 15 & 12.6 & 11.2 & 11.3 & 11.9 & 6 & 3.8 & 15 & 10.26 & 3.93 & \\
\hline & $\begin{array}{l}\text { Post- } \\
\text { monsoon }\end{array}$ & 9.1 & 29 & 22 & 16 & 13.2 & 12.3 & 5.3 & 5.3 & 29 & 15.27 & 8.01 & \\
\hline & Summer & 7.4 & 10.32 & 11 & 11.22 & 13.4 & 14.1 & 4.4 & 4.4 & 14.1 & 10.26 & 3.38 & \\
\hline \multirow{4}{*}{$\begin{array}{l}\text { Nitrogen } \\
\text { (mg/L) }\end{array}$} & $\begin{array}{l}\text { Pre- } \\
\text { monsoon }\end{array}$ & 2.2 & 3.8 & 3.1 & 3 & 2.4 & 2.6 & 2.1 & 2.1 & 3.8 & 2.74 & 0.60 & \multirow{4}{*}{50} \\
\hline & Monsoon & 1.3 & 4.1 & 3.6 & 3.1 & 2.9 & 2.92 & 1.8 & 1.3 & 4.1 & 2.82 & 0.97 & \\
\hline & $\begin{array}{l}\text { Post- } \\
\text { monsoon }\end{array}$ & 2.68 & 2.4 & 2.8 & 2.84 & 2.4 & 2.3 & 1.9 & 1.9 & 2.84 & 2.47 & 0.33 & \\
\hline & Summer & 1.36 & 3.92 & 3.42 & 3.21 & 3.14 & 2.8 & 2.2 & 1.36 & 3.92 & 2.86 & 0.85 & \\
\hline \multirow{4}{*}{$\begin{array}{l}\text { Phosphate } \\
\text { (mg/L) }\end{array}$} & $\begin{array}{l}\text { Pre- } \\
\text { monsoon }\end{array}$ & 1.83 & 4.9 & 4.6 & 3.2 & 3.2 & 3.6 & 1.2 & 1.2 & 4.9 & 3.22 & 1.35 & \multirow{4}{*}{10} \\
\hline & Monsoon & 1.63 & 5.12 & 4.4 & 3.9 & 3.9 & 4 & 2.14 & 1.63 & 5.12 & 3.58 & 1.25 & \\
\hline & $\begin{array}{l}\text { Post- } \\
\text { monsoon }\end{array}$ & 3.6 & 3.9 & 4.1 & 3.94 & 3.5 & 4.1 & 2.2 & 2.2 & 4.1 & 3.62 & 0.67 & \\
\hline & Summer & 1.7 & 4.9 & 4.3 & 3.84 & 4.22 & 3.88 & 2.3 & 1.7 & 4.9 & 3.59 & 1.15 & \\
\hline
\end{tabular}




\section{RESULTS AND DISCUSSION}

\section{$\mathrm{pH}$ and Conductivity}

All the samples had their $\mathrm{pH}$ values between 6.88 to 8.6 and these were well within the permissible limit of 6.5 to 8.5 prescribed for drinking water by Indian standards. The $\mathrm{pH}$ of water in the study area is found to be alkaline in nature. The highest $\mathrm{pH}$ value was observed in running water into the canal at the two locations Chunambu Oodai and convent school (Figure 2a) in post-monsoon and a significant difference was noted in the observed $\mathrm{pH}$ which may be due to the dilution effect (Mohanakavitha et al., 2019b.) The alkaline nature of groundwater is due to chemicals and water-mixed soap from both industrial and residential environments (Radhakrishnan et al., 2007). The observed values, however, were well within the safe limit for crop production. EC is a good measurement of salinity hazard to crop when using groundwater for irrigation. A Similar trend was also observed in the case of conductivity. The values of conductivity ranged from 306 to $8280 \mathrm{mmhos} / \mathrm{cm}$ regarding the highest conductivity at convent school (Figure $2 \mathrm{~b}$ ) maybe due to the mixing of dyeing wastewater. The lowest conductivity may be due to the dilution effect of rain water. The conductivity value was found not with in the permissible limit. If the EC value exists at $3000 \mathrm{mmhos} / \mathrm{cm}$, the production of as in almost all crops would be affected and the yield might be reduced significantly (Srinivas et al., 2000; Sacchidananda and Prakash, 2006).

\section{Total dissolved solids}

The total dissolved solids (TDS) of the different sites of canal water samples where the flows of water in the canal were found within the permissible limit $(1000 \mathrm{mg} / \mathrm{l})$ of WHO standards. If the TDS value exceeds the permissible limit, the water is not suitable for drinking purposes (Sandeep Arya et al., 2011). Due to the nature of flow runoff water occur during heavy rainy seasons certain variation may occurred but this variation did affect the irrigation system. The values of TDS ranged from 307.14 to $2778.86 \mathrm{mg} / \mathrm{l}$. The high TDS values of water samples collected in no flow of water into the canal, which is in the Chunnambu Oodai and Convent School (Figure 3) in post-monsoon. These two locations have dyeing units. These also confirm the fact that the discharge of effluents from dyeing units into the canal water may also be the reason for the very high TDS values observed for the samples collected from other locations which are having many dyeing units (Balusamy and Indrani, 2018).

\section{Total suspended solids}

The values of TSS ranged from 3.51 to $47.79 \mathrm{mg} / \mathrm{l}$. Although all the effluents had a higher concentration of total suspended solids, the sewage effluent at the top had very high values (Balusamy and Indrani, 2018). Spatial-temporal variation shows a high concentration of TSS during the post-monsoon period (Figure 4). The suspended solids determination is particularly useful in the analysis of sewage and other wastewaters and is as significant as BOD determination (Kulandaivel et al., 2009). It is used to evaluate the strength of domestic waste waters and efficiency of treatment units. Suspended solids are objectionable in the canal for many reasons. Suspended solids containing much organic matter may cause putrefaction and may be devoid of dissolved solids. The concentration of TSS at all points was collected in no flow of water into the canal which may be attributed to the direct discharge of domestic and industrial waste.
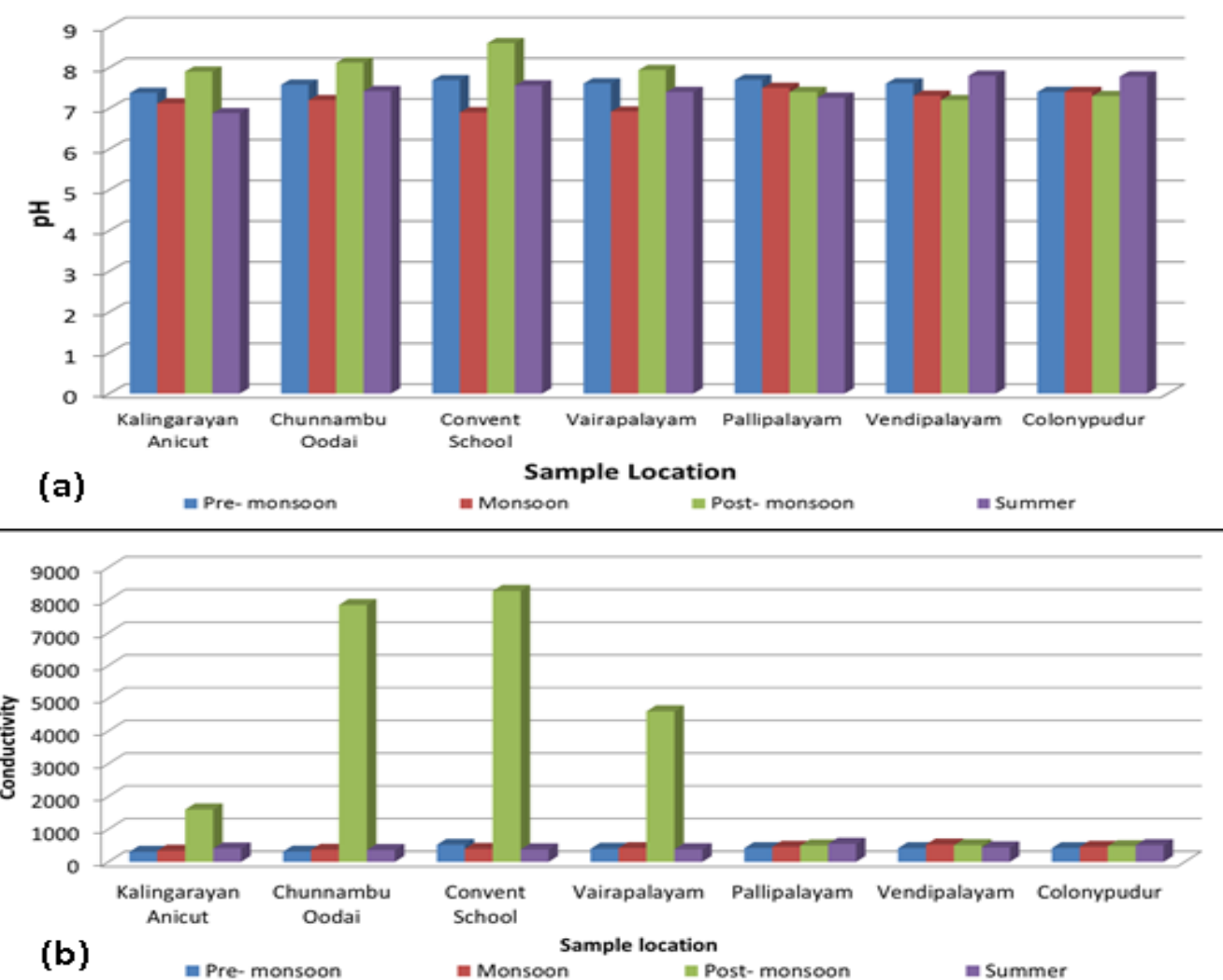

Figure 2. Spatio-temporal variation of (a) $\mathrm{pH}$, (b) Conductivity (mmhos/cm). 


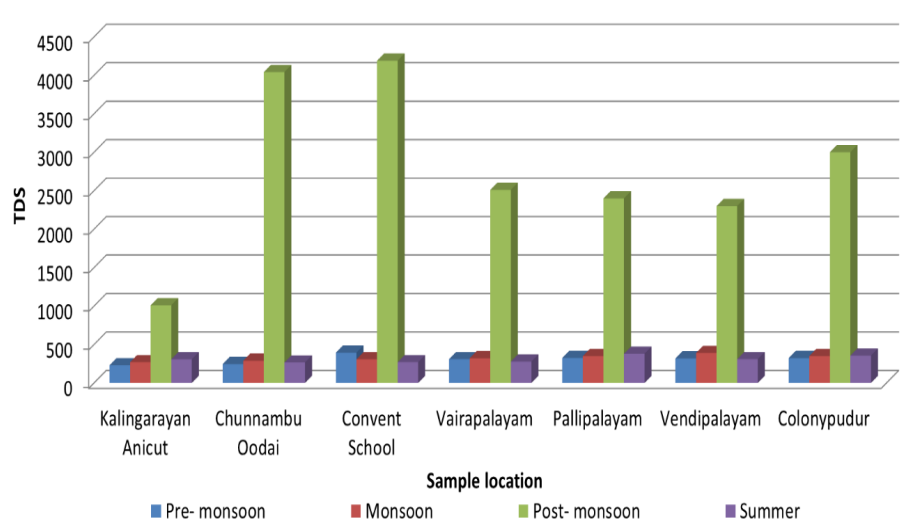

Figure 3. Spatio-temporal variation of TDS $(\mathrm{mg} / \mathrm{L})$.

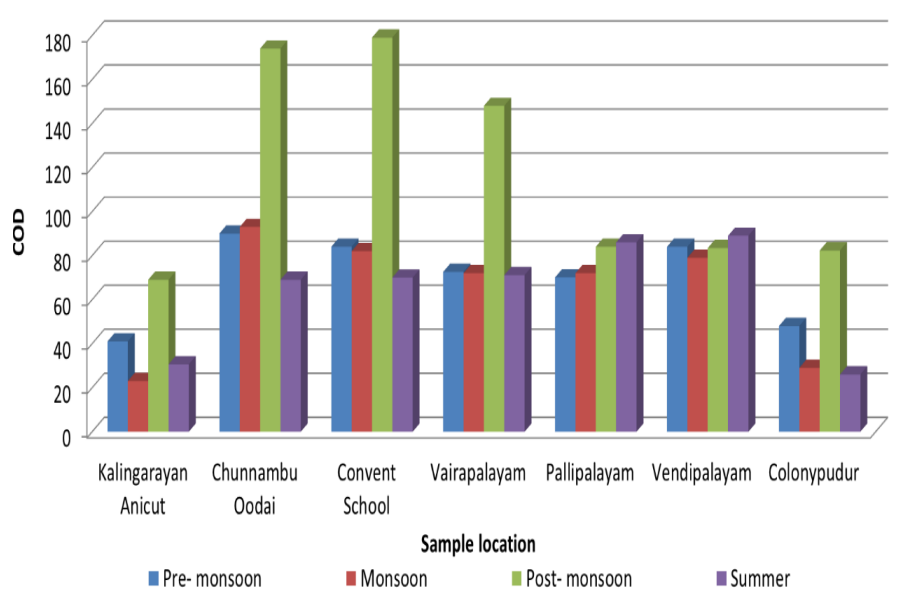

Figure 5. Spatio-temporal variation of $\operatorname{COD}(\mathrm{mg} / \mathrm{L})$.

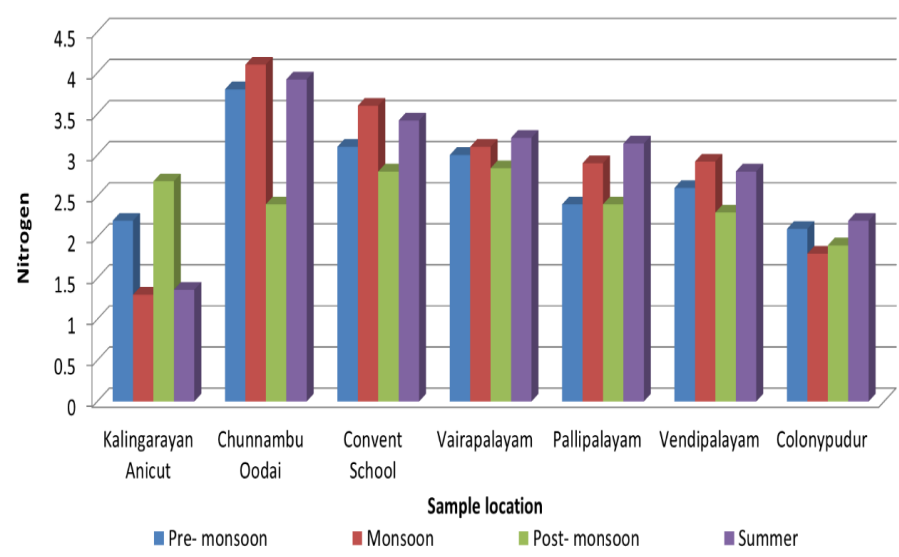

Figure 7. Spatio-temporal variation of Nitrogen $(\mathrm{mg} / \mathrm{L})$.

\section{Chemical oxygen demand}

COD test is quite useful in finding the pollution strength of industrial waste and sewage. Chemical oxygen demand is the amount of oxygen required for a sample to oxidize at its organic and inorganic matter (Sivakumar et al., 2010). The COD value of the canal investigated ranged from $23 \mathrm{mg} / \mathrm{L}$ to $179 \mathrm{mg} / \mathrm{L}$. The highest value of COD was observed at point Convent School (Figure 5) could link with the inflow of the dyeing unit's effluent which is being discharged into the canal. The higher COD values in the samples indicate the presence of an increased concentration of industrial pollutants containing inorganic and organic substances, thus showing a greater toxicity level (Balusamy and Indrani, 2018).

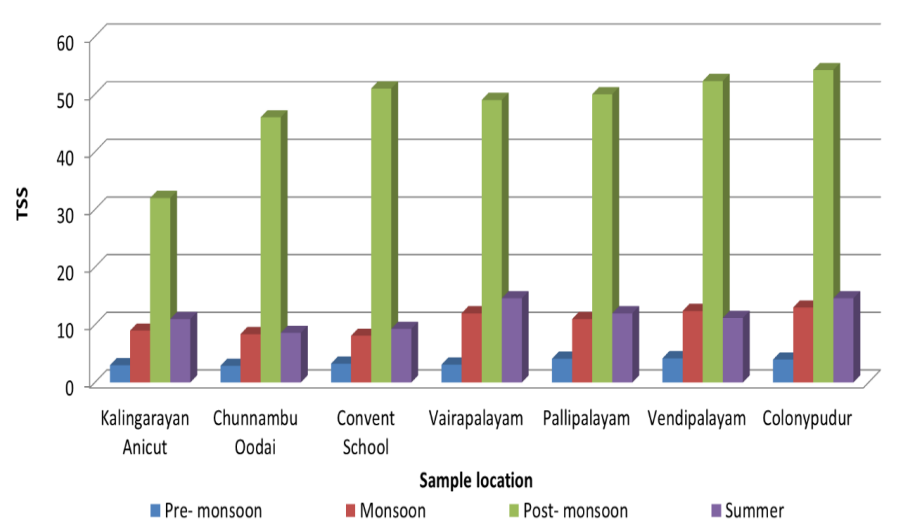

Figure 4. Spatio-temporal variation of TSS ( $\mathrm{mg} / \mathrm{L})$.

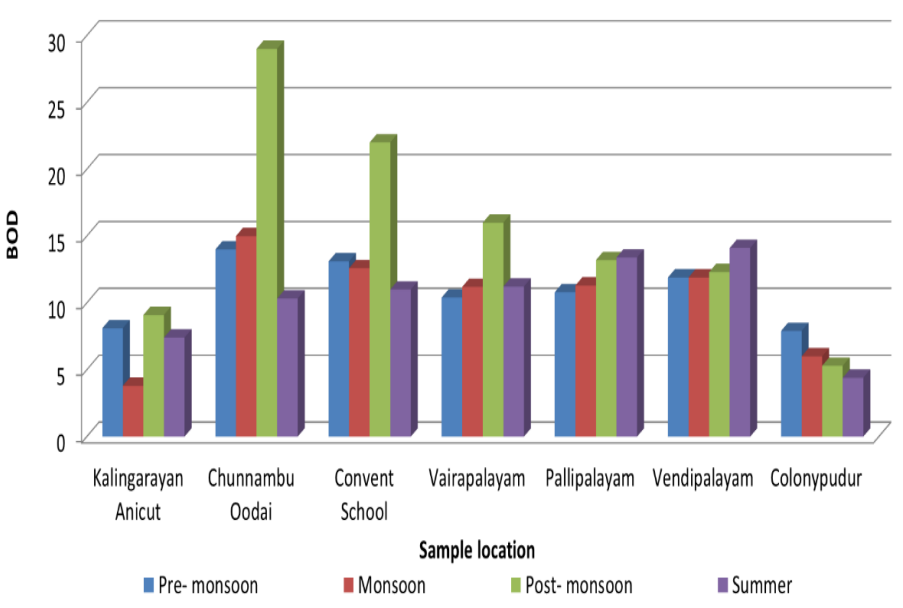

Figure 6. Spatio-temporal variation of $B O D(\mathrm{mg} / \mathrm{L})$.

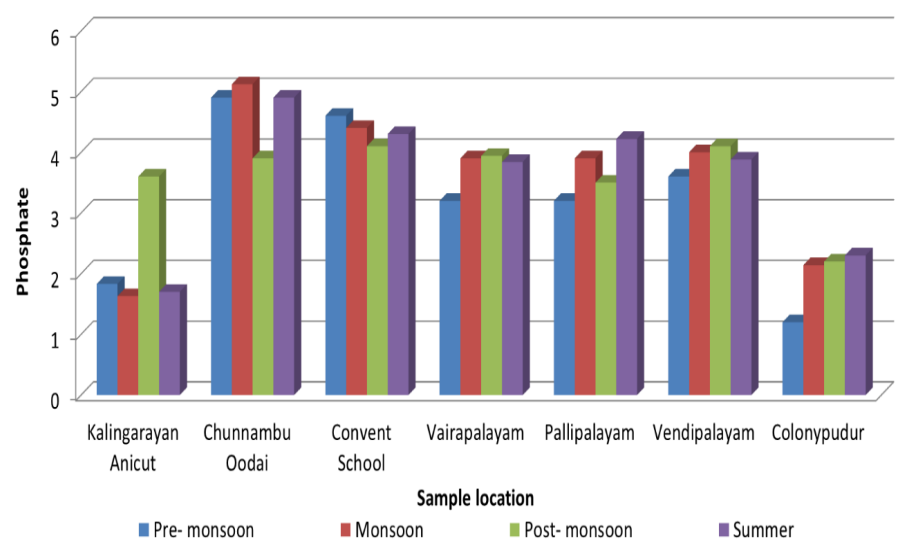

Figure 8. Spatio-temporal variation of Phosphate $(\mathrm{mg} / \mathrm{L})$.

\section{Biochemical oxygen demand}

BOD determination is still the best available single test for assessing organic pollution. BOD concentration found in 3.8 to $29 \mathrm{mg} / \mathrm{L}$ in all seasons indicating here water is highly polluted. The observed BOD of water samples value was an indication for the entry of organic waste in the canal (Usharani et al., 2010). The high BOD values suggest more waste product or pollutants are present in Chunnambu Oodai (Figure 6). This may be a result of the escape of organic matter into the canal mostly from fecal deposition by the surrounding populace. During its flow, a significant part of its organic matter, originating from domestic sewage and industrial effluents, is carried by canal water (Kulandaivel et al., 2009). 


\section{Nitrogen}

The nitrogen content in irrigation water is generally considered beneficial, barring the nitrate form of nitrogen (Grasshoff et al., 1999). It also contained that discharge of ammonium nitrogen and subsequent oxidation that could reduce the DO level in the canal (Khaiwal et al., 2003). The nitrogen concentration of the water sample ranged from $1.3 \mathrm{mg} / \mathrm{L}$ to $4.1 \mathrm{mg} / \mathrm{L}$ (Figure 7). Both phosphate and nitrate are component of agricultural fertilizer commonly used by farmers within the state. These fertilizers may be leached into the soil and river bodies and this may account for significant concentration observed in this study (Rajaram et al., 2005; Ashok Prabu et al., 2005).

\section{Phosphate}

Phosphates are obtained from the rocks converting them into its soluble forms and may also occur in agricultural runoff, industrial wastes, municipal sewage and synthetic detergents. The high concentration of phosphate is always indicative of eutrophic (Fareed and Abid, 2005). The phosphate concentra- tion of the canal ranged from $1.2 \mathrm{mg} / \mathrm{L}$ to $5.12 \mathrm{mg} / \mathrm{L}$ which was found to be above the permissible limit $(0.1 \mathrm{mg} / \mathrm{L})$. The spatialtemporal variation shows a high concentration in the postmonsoon period (Figure 8). The maximum level of phosphate was found in the canal water where it receives maximum sewage, domestic wastes and human activities (Saravanaraja et al., 2017). The use of detergent may increase the phosphate concentration to a great extent. The anthropogenic additions of phosphorus to the canal have a considerable effect on the quality of the water. Such phosphorus is derived mainly from domestic sewage and the runoff from agricultural areas (Usharani et al., 2010). The quantity of phosphorus in the domestic sewage and land drainage have increased considerably in recent years due to the increased use of synthetic detergents which contain approximately by weight, the inorganic condensed purposes and the detergents would enhance a load of this element. A higher amount of phosphate represent high pollution loads and causes eutrophication of the aquatic body.

Table 4a. Correlation matrix analysis result for Pre- monsoon.

\begin{tabular}{|c|c|c|c|c|c|c|c|c|}
\hline & $\mathrm{pH}$ & Conductivity & TDS & TSS & COD & BOD & Nitrogen & Phosphate \\
\hline $\mathrm{pH}$ & 1.000 & & & & & & & \\
\hline Conductivity & 0.557 & 1.000 & & & & & & \\
\hline TDS & 0.582 & 0.997 & 1.000 & & & & & \\
\hline TSS & 0.163 & 0.416 & 0.439 & 1.000 & & & & \\
\hline COD & 0.812 & 0.303 & 0.331 & -0.041 & 1.000 & & & \\
\hline BOD & 0.747 & 0.214 & 0.230 & -0.200 & 0.961 & 1.000 & & \\
\hline Nitrogen & 0.487 & -0.072 & -0.051 & -0.574 & 0.808 & 0.868 & 1.000 & \\
\hline Phosphate & 0.770 & 0.201 & 0.214 & -0.295 & 0.940 & 0.988 & 0.881 & 1.000 \\
\hline
\end{tabular}

Table 4b. Correlation matrix analysis result for Monsoon.

\begin{tabular}{|c|c|c|c|c|c|c|c|c|}
\hline & $\mathrm{pH}$ & Conductivity & TDS & TSS & COD & BOD & Nitrogen & Phosphate \\
\hline $\mathrm{pH}$ & 1.000 & & & & & & & \\
\hline Conductivity & 0.521 & 1.000 & & & & & & \\
\hline TDS & 0.533 & 0.999 & 1.000 & & & & & \\
\hline TSS & 0.458 & 0.781 & 0.784 & 1.000 & & & & \\
\hline COD & -0.195 & 0.188 & 0.182 & -0.259 & 1.000 & & & \\
\hline BOD & -0.149 & 0.183 & 0.180 & -0.240 & 0.991 & 1.000 & & \\
\hline Nitrogen & -0.268 & 0.033 & 0.032 & -0.352 & 0.968 & 0.984 & 1.000 & \\
\hline Phosphate & -0.190 & 0.127 & 0.124 & -0.293 & 0.992 & 0.998 & 0.990 & 1.000 \\
\hline
\end{tabular}

Table 4c. Correlation matrix analysis result for Post-Monsoon.

\begin{tabular}{|c|c|c|c|c|c|c|c|c|}
\hline & $\mathrm{pH}$ & Conductivity & TDS & TSS & COD & BOD & Nitrogen & Phosphate \\
\hline $\mathrm{pH}$ & 1.000 & & & & & & & \\
\hline Conductivity & 0.909 & 1.000 & & & & & & \\
\hline TDS & 0.494 & 0.747 & 1.000 & & & & & \\
\hline TSS & -0.275 & -0.004 & 0.580 & 1.000 & & & & \\
\hline COD & 0.811 & 0.967 & 0.815 & 0.209 & 1.000 & & & \\
\hline BOD & 0.693 & 0.889 & 0.713 & 0.038 & 0.883 & 1.000 & & \\
\hline Nitrogen & 0.728 & 0.537 & -0.052 & -0.426 & 0.481 & 0.414 & 1.000 & \\
\hline Phosphate & 0.486 & 0.507 & 0.110 & -0.184 & 0.488 & 0.636 & 0.749 & 1.000 \\
\hline
\end{tabular}

Table 4d. Correlation matrix analysis result for summer.

\begin{tabular}{|c|c|c|c|c|c|c|c|c|}
\hline & $\mathrm{pH}$ & Conductivity & TDS & TSS & COD & BOD & Nitrogen & Phosphate \\
\hline $\mathrm{pH}$ & 1.000 & & & & & & & \\
\hline Conductivity & 0.125 & 1.000 & & & & & & \\
\hline TDS & 0.018 & 0.990 & 1.000 & & & & & \\
\hline TSS & 0.180 & 0.480 & 0.478 & 1.000 & & & & \\
\hline COD & 0.233 & -0.034 & -0.126 & -0.291 & 1.000 & & & \\
\hline BOD & 0.074 & -0.051 & -0.120 & -0.318 & 0.973 & 1.000 & & \\
\hline Nitrogen & 0.355 & -0.288 & -0.393 & -0.365 & 0.712 & 0.558 & 1.000 & \\
\hline Phosphate & 0.299 & -0.245 & -0.347 & -0.456 & 0.839 & 0.721 & 0.972 & 1.000 \\
\hline
\end{tabular}




\section{Correlation matrix analysis}

The correlation coefficient is the relationship between the variables and the measurement of one variable depends on other variables or not. In order to identify the relationship between the physicochemical parameters of the water samples, correlation coefficients have been established and a large number of significant correlations have been obtained (Helena et al., 2000; Usharani et al., 2010). A correlation matrix was generated for 8 variables for four different seasons pre-monsoon, monsoon, post-monsoon and summer (Table 4a, b, c, d). The correlation coefficient ranges between -1 and +1 . The values found above 0.5 have been highlighted and considered for the relationship study. If the correlation coefficient is between 0.5 and $0.8, a$ moderate relationship was considered and above 0.8 , a strong relationship was considered (Vishwakarma et al., 2019). It is clear from the results that the TSS was negatively correlated with all variables and was not significantly correlated with any of the parameters in all seasons. During the Pre-monsoon and monsoon (Table 4a, b) strong correlation is exhibited between EC with TDS; COD with BOD, nitrogen, Phosphate; BOD with nitrogen, Phosphate; Nitrogen with Phosphate. Moderate correlation exhibits between $\mathrm{pH}$ with $\mathrm{EC}$, TDS, BOD, Phosphate (Pre-monsoon); $\mathrm{pH}$ with TDS in monsoon, indicates the discharge of sewage, domestic wastes and human activities. In post -monsoon due to dilution effect strong correlation between $\mathrm{pH}$ with EC, COD; EC with COD, BOD; TDS with COD; COD with BOD. Moderate correlation is between $\mathrm{pH}$ with BOD and Nitrogen; EC with TDS, nitrogen, Phosphate; TDS with TSS, BOD; BOD and Nitrogen with Phosphate. In summer the strong correlation between EC with TDS; COD with BOD, Phosphate; Nitrogen with Phosphate; a moderate correlation between COD with Nitrogen; BOD with Nitrogen with Phosphate. The correlation analysis is identified that EC, COD, BOD, Nitrogen, find higher- level correlation significance with water quality parameters in all seasons. It provides a means to monitor the quality of water in an area more easily and quickly. Achuthan Nair et al., 2005 concluded that a correlation analysis and correlation coefficient values can help to identify treatments to mitigate groundwater pollution.

Impact of industrial wastewater disposal on surface water bodies

Effluents if released prior to treatment, harm the water bodies as well as the paths through which they traverse, as the pollutants in these effluents are still in their complex form and can therefore not be degraded by the micro-flora and fauna The leather processing or the tannery industry has very complex by-products as a result of its activities and hence has among its varied components, a high amount of chrome compounds as well as other miscellaneous heavy metals. The textile industry on the other hand has effluents rich in salts such as sodium chloride and sodium sulphate. In addition to these, effluents are also known for their highly objectionable odour. Kalingarayan Canal, the lifeline of hundreds of farmers in the district, now faces fresh onslaught of pollution.

\section{Conclusion}

The analysis showed that the quality of the Kalingarayan canal in the study area is significantly affected by the discharge of toxic effluents and sewage water. It is observed that during non flow times of canal water the effluents discharged by the dyeing units and sewage discharged by the near by residences deposits in the canal itself which is cause of the increase pollution. Due to the discharge of sewage, domestic wastes and human activities the phosphate load in canal water exceeds the permissible limit. Since the sewage mixes with the canal, the canal water cannot be used for irrigation and drinking purposes. Regular monitoring of canal and taking suitable remedial measures like collection of domestic sewage and setting up the common treatment plant before discharge of sewage into canal. Wastewater should be treated. This will control pollution and prevent the depletion of the quality of canal water.

\section{Conflict of interest}

The authors declare there are no conflicts of interest.

Open Access: This is an open access article distributed under the terms of the Creative Commons Attribution 4.0 License, which permits unrestricted use, distribution, and reproduction in any medium, provided the original author(s) if the sources are credited.

\section{REFERENCES}

Abdul Bari, J. and Vennila, G. (2014). Study on Ground Water Quality of Bhavani Taluk, Erode District, Tamilnadu, India. International Journal of Earth Sciences and Engineering, 7 (2): 475-478.

Abdul Bari, J. Vennila, G. and Shanmugaraja, T.M. (2015). Physico-Chemical Characteristics of Groundwater of Bhavani Block, Erode District, Tamilnadu, India. Rasayan Journal of Chemistry, 8(2): 198-202.

Achuthan Nair, G., Abdullah, I.M., Mahamoud, M.F. (2005). Physio-chemical parameters and correlation coefficients of ground waters of North-East Libya. Pollution Research, 24(1): 1- 6.

APHA. (2012). Standard Methods for Examination of Water and Wastewater', $21^{\text {st }}$ Ed., American Public Health Association, American Water Works Association.

Aravindan, S. and Shankar, K. (2011). Ground Water Quality Maps of Paravanar River Sub Basin, Cuddalore District, Tamil Nadu, India. Journal of Indian Society of Remote Sensing, 39(4): 565-58, https://dx.doi.org/10.1007/s12524-011-0152-9

Aravindan, S. and Shankar, K. (2011). Trace element concentration mapping in groundwater of Paravanar River Sub-Basin, Cuddalore District, Tamilnadu using Geospatial Technique. Journal of Applied Geochemistry, 54-67.

Aravindan, S., Manivel, M., Rajendran, S., Bhuvaneshwari, Shankar, K. (2008). Groundwater Investigations in the hard rock region of gadilam river basin, Tamil Nadu. Journal of Eco-chronicle, 3(1): 21-30.

Aravindan, S., Shankar, K. and Mini, S.S. (2011). Integrated Geohydrological Studies in the Sedimentary Part of Gadilam River Basin, Cuddalore District, Tamil Nadu. Asian Journal of Earth Sciences, 4: 183-192, https://dx.doi.org/10.3923/ajes.2011.183.192

Aravindan, S., Shankar, K., Poovalinga Ganesh, B., Dharani Rajan, K. (2010). Groundwater Geochemical mapping of in the hard rock area of Gadilam River basin, using GIS technique, Tamil Nadu. Indian Journal of Applied Geochemistry, 12(2): 209-216.

Ashok Prabu, V., Rajkumar, M., and Perumal, P. (2008). Seasonal variations in physico-chemical characteristics of pichavaram mangroves, southeast coast of India. Journal of Environmental Biology, 29: 945-950.

Balusamy, K. and Indrani, T. (2018). Water Quality Assessment in Kalingaraya Canal - A Distributary of River Bhavani Erode District, Tamilnadu. International Journal of Life Sciences Research, 6(2): 28-36). 
BIS 1982, Indian Standard for Tolerance limits for Inland Surface water subject to pollution IS: 2296, Bureau of Indian Standards, New Delhi.

BIS 1991, Indian Standard for Drinking Water Specifications IS: 10500, Bureau of Indian Standards, New Delhi.

Chandan Chakraborty., Md Mazaharul Huq., Sobur Ahmed and Md Rubel Miah. (2013). Analysis of the Causes and Impacts of Water Pollution of Buriganga River: A Critical Study. International Journal of Scientific \& Technology Research, 2(9): 245-252.

Fareed A. Khan. and Abid Ali Ansari. (2005). Eutrophication: An Ecological Vision. Botanical Review, 71(4): 449-482, www.jstor.org/stable/4354503

Gayathri Purushothaman, Sunitha and Mahimairaja. (2013). Assessment of ground water contamination in Erode District, Tamilnadu. Academic Journals, 7(6): 563-566.

Geetha, A., Palanisamy, P.N., Sivakumar, P., Ganesh Kumar, P. and Sujatha, M. (2008). Assessment of underground water contamination and effect of textile effluents on Noyyal River basin in and around Tiruppur Town, Tamil Nadu. European Journal of Chemistry, 5(4): 696-705.

Govingarajalu, K. (2003). Industrial effluent and health status- A case study of Noyyal river basin. Proceedings of third International Conference on Environment and Health, Chennai, India. 150-157.

Grasshoff, K., Ehrhardt, M. and Bkremling, K. (1999). Methods of seawater analysis," Wiley- VCH, Hoboken, pp. 159-226.

Kawo, N.S. and Karuppannan, S. (2018). Groundwater quality assessment using water quality index and GIS technique in Modjo River Basin, central Ethiopia. Journal of African Earth Sciences, 147: 300-311, https://doi.org/10.1016/j.jafrearsci.2018.06.034

Khaiwal, R., Ameena, M., Monika, R. and Kaushika, A. (2003). Seasonal variations in physico -chemical characteristics of river yamuna in Haryana and its ecological best designated use. Journal of Environmental Monitoring, 5: 419-426.

Kiran, V. Mehta (2010). Physicochemical characteristics and statistical study of groundwater of some places of Vadgam taluka in Banaskantha district of Gujarat state (India). Journal of Chemical and Pharmaceutical Research, 2(4): 663-670.

Kulandaivel, A.R.K., Kumar, P.E. and Magudeswaran, P.N. (2009). Water quality assessment of Kalingarayan canal at Erode district, Tamilnadu (India). Current World Environment, 4(1): 199-202, http://dx.doi.org/10.12944/CWE.4.1.34

Kumar, V., Kumar, S., Srivastava, S., Singh, J. and Kumar, P. (2018). Water quality of River Ganga with reference to physico-chemical and microbiological characteristics during Kanwar Mela 2017, at Haridwar, India: A case study. Archives of Agriculture and Environmental Science, 3(1): 58-63, https://doi.org/10.26832/24566632.2018.030108

Kumar, V., Singh, J. and Kumar, P. (2019). Heavy metal uptake by water lettuce (Pistia stratiotes L.) from paper mill effluent (PME): experimental and prediction modeling studies. Environmental Science and Pollution Research, 26(14): 14400-14413, https://doi.org/10.1007/s11356-019-04766-29

Mahalakshmi, G., Kumar, M. and Ramasamy, T. (2018). Assessment of Surface Water Quality of Noyyal River Using Wasp Model. Asian Journal of Engineering and Applied Technology, 7(1): 37-40.

Mariraj Mohan, S. and Vanalakshmi, P. (2013). Assessment of Water Quality in Noyyal River through Water Quality Index. International Journal of Water Resources and Environmental Engineering, 5(1): 35-48.

Mohanakavitha, T., Divahar, R., Meenambal, T., Shankar, K., VijaySingh, R., Tamirat Dessalegn Haile and Chimdi Gadafa. (2019a). Dataset on the assessment of water quality of surface water in Kalingarayan Canal for heavy metal pollution, Tamil Nadu. Data in Brief, 22: 878-884, https://doi.org/10.1016/j.dib.2019.01.010

Mohanakavitha, T., Divahar, R., Meenambal, T. and Keredin Temam Siraj. (2019b). Assessment of Water Quality of Surface Water in Kalingarayan Canal for Heavy Metal Pollution, Tamil Nadu. Indian Journal of Ecology, 46(1): 49-54.

Mohanakavitha, T. and Meenambal, T. (2013). Assessment of Water Quality Index for the Groundwater in Downstream Side of the Kalingarayan Canal, Erode District, Tamil Nadu State, India. Pollution Research, 32(02): 245-249.

Palanisamy, P.N., Geetha, A., Sujatha, M., Sivakumar, P. and Karunakaran, K. (2007). Assessment of ground water quality in and around Gobichettipalayam Town Erode district, Tamil Nadu. European Journal of Chemistry, 4 (3): 434-439.

Radhakrishnan, R., Dharmaraj, K. and Ranjithakumari, B.D. (2007). A Comparative study on physico chemical and bacterial analysis of drinking, bore well and sewage water in the three different places of Sivakasi. Journal of Environmental Biology, 28(1): 105-108.

Rajaram, R., Srinivasan, M. and Rajasegar, M. (2005). Seasonal distribution of physico- chemical parameters in effluent discharge area of Uppanar estuary, Cuddalore, Southeast coast of India. Journal of Environmental Biology, 26: 291-297.

Samuel Rajkumar, A. and Nagan, S. (2011). Study on Tiruppur CETPs discharge and their impact on Noyyal River and Orathupalayam dam, Tamil Nadu, (India). Journal of Environmental Research and Development, 5(3).

Sandeep Arya., Vinit Kumar., Minakshi and Anshu Dhaka. (2011). Assessment of Underground water quality: A case study of Jhansi City, Uttar Pradesh, India. International Multidisciplinary Research Journal, 1(7): 11-14.

Saravanaraja, M., Aruna Devi, P.S. and Ananda Kumaran, S. (2017). Impact of urbanization on the Hysicochemical characteristics and its sequential changes in the ethano-botanical composition of the Odathurai lake of Erode district, South India. International Journal of Current Research, 9(9): 5771657720.

Shankar, K., Aravindan, S. and Rajendran, S. (2011a). Spatial distribution of groundwater quality in Paravanar river sub basin, Cuddalore district, Tamil Nadu. International Journal of Geomatics and Geosciences, 1(4): 914-931.

Shankar, K., Aravindan, S. and Rajendran, S. (2011). Assessment of Ground Water Quality in Paravanar River Sub-Basin, Cuddalore district, Tamil Nadu, India. Advances in Applied Science Research, 2 (5): 92-103.

Shankar, K., Aravindan, S., Rajendran, S. (2011b). Hydrogeochemistry of the Paravanar River Sub-Basin, Cuddalore District, Tamilnadu, India. E-Journal of Chemistry, 8(2): 835-845, https://doi.org/10.1155/2011/107261

Shankar, K., Aravindan, S., Rajendran, S. (2010). GIS based groundwater quality mapping in Paravanar River Sub-Basin, Tamil Nadu, India. International Journal of Geomatics and Geosciences, 1(3): 282-296.

Shankar, K., Aravindan, S., Rajendran, S. (2011). Hydrochemical profile for assessing the groundwater quality of Paravanar River Sub-Basin, Cuddalore district, Tamil Nadu, India. Current World Environment, 6(1): 45-52.

Sivakumar, K. K., Balamurugan, C., Ramakrishnan, D. and Leena Hebsibai, L. (2011). Studies on physicochemical analysis of ground water in Amaravathi River basin at Karur (Tamil Nadu), India. Water Research and Development, 1(1): 36-39.

Sivakumar, V., Asaithambi, M., Jayakumar, N., Sivakumar, P. (2010). Assessment of the Contamination from the Tanneries and Dyeing Industries on to Kalingarayan Canal of Tamilnadu. International Journal of Research Chem Tech. 2(2): 774-779.

Srinivas, C.H., Ravi Shankar Piska., Venkatesa, C., Sathya Narayan Rao, M.S. and Ravinder Reddy R. (2000). Studies on ground water quality of Hyderabad. Pollution Research, 19(2): 285-289.

Sutharsiny, A., Pathmarajah, S., Thushyanthy, M. and Meththinka, V. (2012). Characterization of Irrigation Water Quality of Chunnakam Aquifer in Jaffna Peninsula. Tropical Agricultural Research, 23(3): 237-248, http://doi.org/10.4038/tar.v23i3.4661

Tenagne Addisu Wondie, (2009). The impact of urban storm water runoff and domestic waste effluent on water quality of Lake Tana and local groundwater near the city of Bahir Dar, Ethiopia. Faculty of the Graduate School of Cornell University.

Thoker Farook Ahmed., Manderia Sushil and Manderia Krishna. (2012). Impact of Dye Industrial Effluent on Physicochemical Characteristics of Kshipra River, Ujjain City, India. International Research Journal of Environment Sciences, 1(2): 41-45.

Tripathi, A. and Misra, D. R. (2012). A study of physico- chemical properties and heavy metals in contaminated soils of municipal waste dumpsites at Allahabad, India. International Journal of Environmental Sciences, 2(4): 2024-2033.

Tripathi, B.D., Dwivedi, R.K. and AnamikaTripathi. (1990). Influence of Industrial Wastes on Physico- Chemical properties of soil and germination and mineral composition of Wheat. Journal of Water, Air and Soil Pollution, 49: 107-112.

Usharani, K., Umarani, K., Ayyasamy, P.M., Shanthi, K. and Lakshmanaperumalsamy, P. (2010). Physico-Chemical and Bacteriological Characteristics of Noyyal River and Ground Water Quality of Perur, India. Journal of Applied Sciences and Environmental Management, 14 (2): 29 -35.

Venkateswaran, S., Karuppannan, S. and Shankar, K. (2012). Groundwater Quality in Pambar Sub-Basin, Tamil Nadu, India Using GIS. International Journal of Recent Scientific Research, 3(10): 82- 787.

Vishwakarma, C.A., Sen, R., Singh, N., Singh, P., Rena, V., Rina, K. and Mukherjee, S. (2019). Geochemical Characterization and Controlling Factors of Chemical Composition of Spring Water in a Part of Eastern Himalaya Geochemical Characterization and Controlling Factors of Chemical Composition of Spring Water in a Part of Eastern Himalaya. Journal of Geological Society of India, 92: 753, https://doi.org/10.1007/s12594-018-1098-0

Zahir Hussain, A. and Rajadurai, D. (2013). Assessment of ground water pollution on the bank of river Amaravathi at Karur district, Tamil Nadu. Advances in Applied Science Research, (4):6-10. 